\title{
Analysis of Chemistry Laboratory Implementation in Senior High School
}

\author{
Julia Mardhiya \\ Department of Chemical Education \\ Universitas Negeri Medan \\ Medan, 20222, Indonesia \\ Corresponding email : julia.mardhiya@gmail.com \\ Ramlan Silaban \\ Department of Chemical Education \\ Universitas Negeri Medan \\ Medan, 20222, Indonesia \\ Mahmud \\ Department of Chemical Education \\ Universitas Negeri Medan \\ Medan, 20222, Indonesia
}

\begin{abstract}
Science process skills are closely related to science. One of way to practice science process skills to students is laboratory experiments. Its main activity involves various student activities such as designing experiments, assembling and using equipments, analyzing and predicting data. This study aims to describe the profile of practical implementation and problems of chemistry subject at senior high school in Tanjungpura. The survey using interviews, questionnaires and observations towards to the principal, teachers and student of senior high schools at Tanjung Pura. Survey data were analyzed descriptively. The results obtained show that the practical implementation have less good criteria based on the questionnaire responses of teachers and students. Some aspects that show fairly low percentage is the availability of time, equipment and materials, practical guidance. In addition to the motivational aspect from environment is less supportive practicum. The results also show that there were problem such as laboratory facilities that not utilized; limited school support, lacked laboratory management, low teacher teacher preparation, practical implementation is not helped by a laboratory technician. For next research, there are development of practical guidence and inovation of practical equipment.
\end{abstract}

Keywords - Chemistry lab; Laboratory; Chemistry Learning

\section{INTRODUCTION}

Practical activity involves various student activities such as designing experiments, assembling and using equipments, analyzing and predicting data. Experiments conducted in the laboratory is an integral part of their science lessons that focus psychomotor aspects [1]. Science process skill are closely related to science. Science process skill raise the curiosity and responsibility, improve learning outcomes, and practice scientific attitude [2]. It is important in for learning steps to acquire the knowledge [3]. The main objective in science education is to prepare students to accumulate knowledge of nature and the world and find their own scientific knowledge through the application of science process skills. Science process skills of students can be seen from indicators of science process skills, such as observation, communication, classification, prediction inference, organization of data in the table experimental data analysis, identification of variables and prepare experiment.

One of way to practice science process skills to students are laboratory experiments. Its main activity practice in direct labor process [5]. Experience in the laboratory is the core process of learning science [6]. Practicum can be implemented optimally if it is supported by various components, such as school regulation, teacher competence, and laboratory preperation. School regulation as curriculum implementation in 2013 was used as a reference lab activities in learning chemistry.

Another thing in the practicum in the lab is a quality planning activities and strategies in the implementation and evaluation during the practicum course of the abilities and skills of teachers in practical implementation [7]. The willingness and readiness of the laboratory in an effort to optimize the lab activities. Equipment and materials, the physical condition of the laboratory. Evidence from the field suggests that teachers rarely apply in the learning process chemistry lab. Practicum only done when viewing the summative exam to complete the report psychomotor learning outcomes assessment. Many reasons can be done by the teacher. To find an overview of the implementation of practical activities in teaching chemistry. This study aims to describe the profile of practical implementation and problems of chemistry subjects at senior high school in Tanjungpura.

\section{LITERATURE REVIEW}

Laboratory is one of the means of education that can be used as a place to practice, students can make contact with the 
object to be studied directly either through observation or by experiment, from the laboratory that will always flow of information-new scientific information derived from the results of the findings of researchers in the laboratory [8].

Practicum can be interpreted as a series of activities that allow students to apply the skills or practicing something. Practicum can be done based on the methodology in accordance with its objectives. In addition to master the practical purpose, practicum must also know the material that supports the facts are there, and the lab can be resolved or concluded [9]. Practicum is a form of teaching that are accurate to skills, understanding and attitudes. Its main activity is the exercise of scientific activity in the form of experiment, observation and demonstration that shows the relationship between the theory of the phenomenon conducted both in laboratory and outside laboratory [10].

Laboratories play an important role in the chemistry of effective learning. Extra hours of practicum for teaching chemistry to be very important. Because, most of the content of science subjects are abstract topics, to make students understand topics such as the need to use student centered learning methods based constructivist. Laboratory is very important to understand chemistry concepts are abstract because the lab, these abstract concepts can be understood into a concrete concept by learners [11]. Many researchers in the field of science education recognizes that laboratory studies to increase the interest and abilities of students for science subjects and to develop cognitive, affective, and psychomotor learners in achieving the objectives lab [12] [13].

\section{METHODS}

The research was conducted form a survey on October 2017. The target object is the principal, teachers and students. The population in this study were students and chemistry teachers at three senior high schools in Tanjung Pura, there were SMA Negeri I Tanjung Pura, MAN 1 Tanjung Pura, and MAN 2 Tanjung Pura. The samples in this study were 82 students of class XI. Teachers selected as samples are 5 teachers who teach chemistry at three schools were selected randomly. Instruments in this study use questionnaire, interview and observation sheet. Questionnaires for teachers and students who are used to retrieve data about the practical implementation. The questionnaire responses of teachers to the practical implementation that has been filled by the teacher sample, then collected for analysis. The statement on the questionnaire responses of teachers to: (1) The practical implementation; (2) motivation of teachers to the practical implementation and (3) evaluation of the results of the lab report. Creating a feedback questionnaire score sample teacher. Each item statement on the questionnaire responses sampled teacher will receive a score is a number will then be calculated. Positive statements are answered "yes" got a score 1, "no" got score 0 and a negative statement is answered "no" to get a score 1, "yes" get score 0 . Interviews were conducted against teachers. After meakukan interviews with sources and the data obtained, then the interview data were analyzed descriptively using cross-checking technique with the
Table 1. Criteria Value

\begin{tabular}{ccc}
\hline No. & Category & Score \\
\hline 1. & Good & $76 \%-100 \%$ \\
2. & Enough good & $56 \%-75 \%$ \\
3. & Less good & $40 \%-55 \%$ \\
4. & Not good & $\leq 40 \%$ \\
\hline
\end{tabular}

questionnaire responses of teachers and students. The interview aims to complete the picture obtained from the analysis of questionnaire data.

Data analysis techniques for the instrument questionnaire and analyzed quantitatively descriptive observations are supported by the results of interviews to determine whether there are obstacles encountered in use in the laboratory. The data obtained and changed using simple tabulation. Determining the percentage of respondents' answers alternative to using the formula:

$$
P=\frac{N}{F} \times 100 \%
$$

Information:

$\mathrm{P}=$ the percentage of the alternative answers.

$\mathrm{F}=$ Frequency of alternative answers.

$\mathrm{N}=$ number of samples.

From the calculation using the above formula generated data in percent (\%), the classification score is then converted into a classification as percentages in the table 1 .

\section{RESULTS AND DISCUSSION}

\section{A.Teacher perspective on the Chemistry Lab a. Laboratory Implementation}

Teachers in the practical implementation perspective seen from several aspects. Through a questionnaire known that the four aspects of obtaining a less good percentage that is the availability of time $(50 \%)$, the availability of teaching materials $(53 \%)$, practical guidance $(50 \%)$, and the availability of tools and materials lab (50\%). This suggests that the practical implementation in high school Tanjung Pura is still relatively less performing well. As for the aspects of the role of teachers, practical conformity with the material and practical assessment is still in good category, but this needs to be improved in view of the importance of learning through practical work on the Curriculum 2013. The percentage of each aspect can be seen in Figure 1.

Laboratory Implementation (\%)

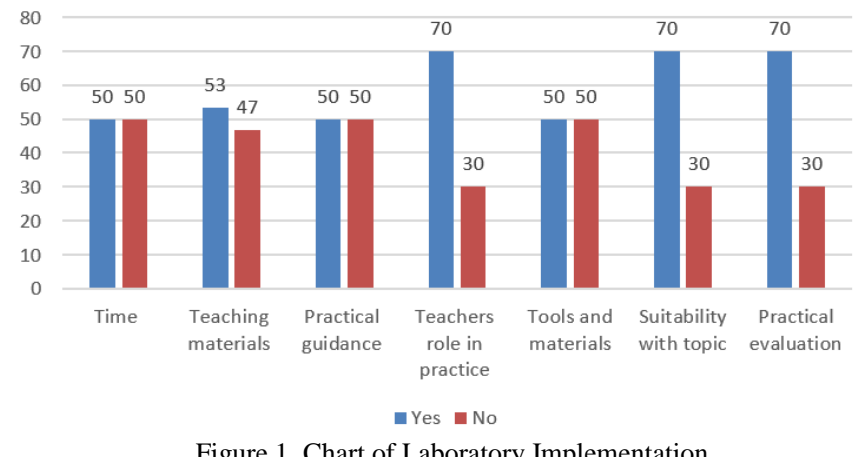

Figure 1. Chart of Laboratory Implementation 
Motivation (\%)

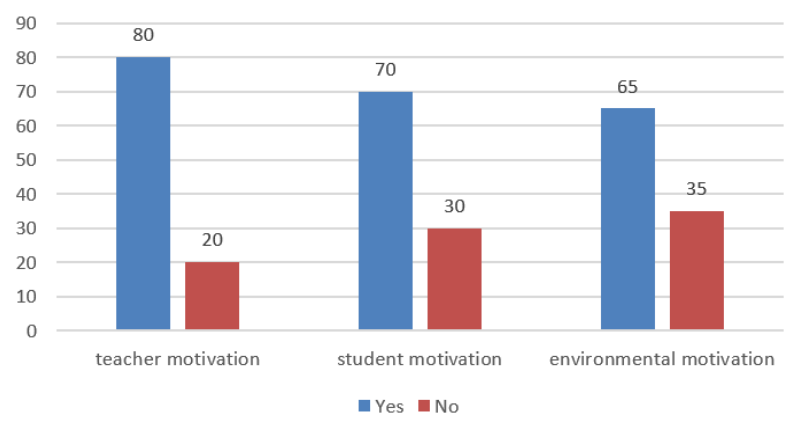

Figure 2. Chart of motivation from teacher Perspectives

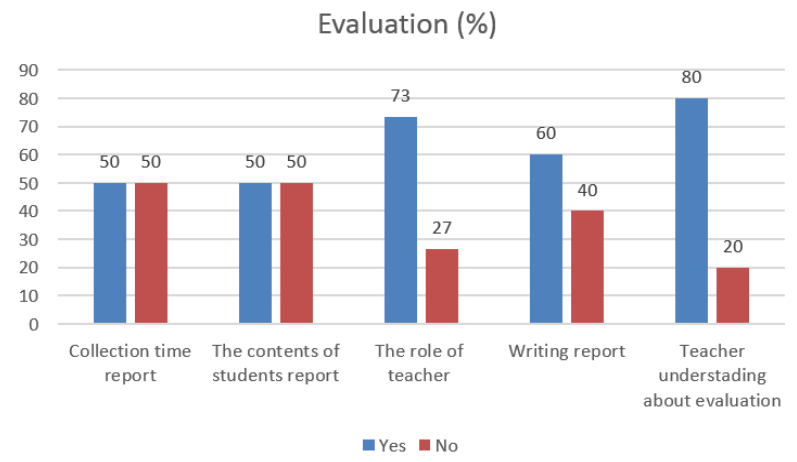

Figure 3. Chart of evaluation from teacher Perspectives

\section{b. Motivation in Chemistry Lab}

The results of the data analysis of a questionnaire on motivation in carrying out practical work with the acquisition of the percentage figure of teacher motivation (80\%), as well as the motivation from students $(70 \%)$ which can be categorized as good, but the motivation from environment is only $65 \%$. Percentage of each aspect can be seen in Figure 2.

\section{c. Lab Evaluation}

In addition to aspects of the implementation and motivation, evaluation aspects lab also is the focus of 2013. Evaluation curriculum includes not only cognitive assessment but also affective and psychomotoric. The questionnaires have been tabulated obtained by percentage of time gathering reports and report content $50 \%, 60 \%$ report writing, the role of teachers $(73 \%)$, and manufacture of value $(80 \%)$. The frequency and the preparation of practical reports seemed still be the hardest thing to do by the practitioner with unfavorable category. Percentage of each aspect can be seen in Figure 3.

\section{B. Student Perspectives on Chemistry Lab \\ a. Laboratory Implementation}

The results of a questionnaire given to students in the practical implementation shows that some aspects are not performing well is time (55\%), teachers role (67\%), the availability of tools and materials (48\%), suitability with topic $(50 \%)$, laboratory place $(54 \%)$. This lack of implementation shows the obstacles facing students in practicum. Percentage of each aspect can be seen in Figure 4.

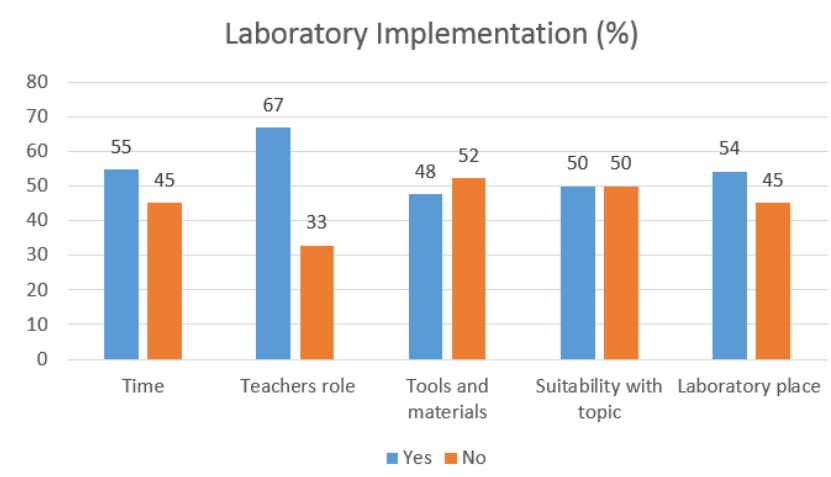

Figure 4. Chart of of Laboratory implementation from student perspectives

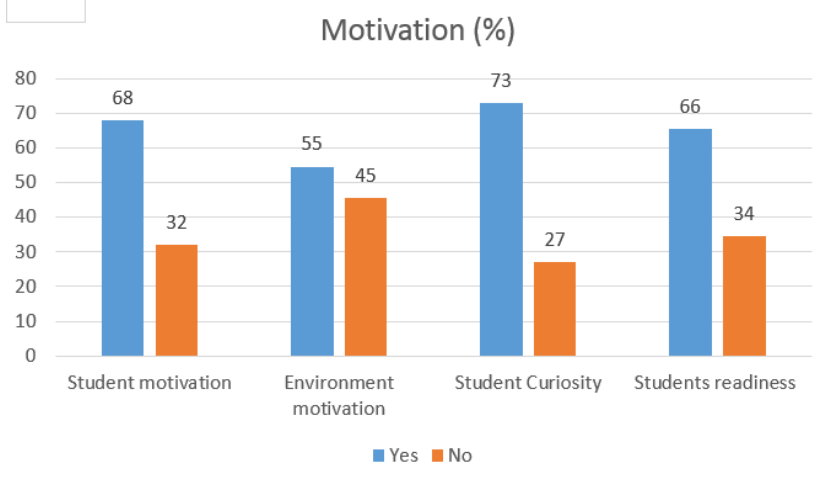

Figure 5. Chart of of motivation implementation from student perspectives Evaluation (\%)

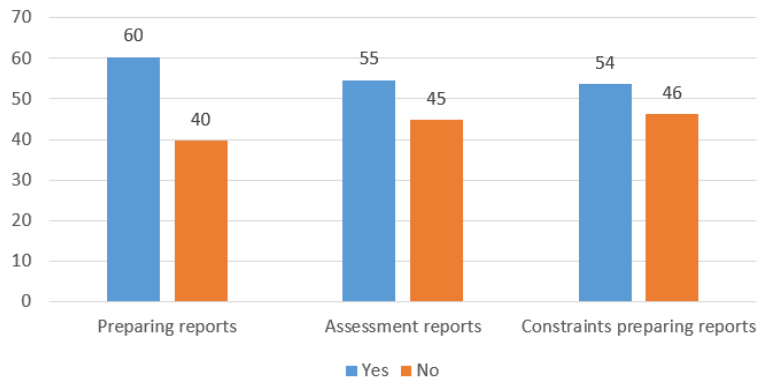

Figure 6. Chart of of evaluation implementation from student perspectives

\section{b. Motivation in Chemistry Lab}

The results of the data analysis of a questionnaire on motivation in carrying out practical work with a scoring percentage of the students motivation $(68 \%)$, motivation from environment (55\%), students curiosity $(73 \%)$, and the students readiness $(66 \%)$. This suggests a fairly good student motivation to carry out lab work, but is not supported by the motivation of the environment. Percentage of each aspect can be seen in Figure 5.

\section{c. Lab Evaluation}

In the practical aspect, the questionnaire showed that preparation of reports $(60 \%)$, assessment reports (55\%), report generation constraints (54\%). Percentage of each aspect can be seen in Figure 6 


\section{Observation Results}

In addition to test the questionnaire on the subject of the study, the researchers conducted observations in the laboratory in October 2016 during the learning lab chemistry takes place. Before the observation instrument was tested to the students beforehand validated to expert lecturers same questionnaire instrument. Observations on the practical implementation of activities carried chemistry learning as a way to collect data that is to know how the lab chemistry implementation. The results of observations of one of the classes at in table 2 . Based on the table 2, it can be seen that the practical implementation of learning chemistry in high school chemistry labs categorized quite good (76\%). Indicators laboratory conditions $50 \%$ categorized as poor. Interest of learners towards practical implementation $78 \%$, a practical implementation $(60 \%)$ with good enough category and preparation practical implementation of $70 \%$ with a category good enough.

\section{Constraints Faced by Teachers}

Management of chemical laboratory facilities and infrastructure is not optimal, it can be evidenced by a lack of awareness of managers to conduct an inventory of tools and materials and not classifying the tools and materials in accordance with its function. Lab space has been used as a place of teaching and learning. The storage space is still in a state of irregular and impressed as a warehouse or a pile of goods. Tools and materials contained in the storage space is not maintained and many are damaged due to prolonged stacked or were eaten by rodents or insects. Such conditions create problems with the practical activities carried out in the laboratory.

Another obstacle is revealed about the funds allocated to the laboratory. Data show that the funds allocated for the lab was minimal. The problem of funds is highly correlated with school policy issues also be other constraints of time that teachers face in carrying out laboratory activities. The nature of chemical science requires skills that the process is more important than the product, because of the limited time the teacher should have been smarter to make learning strategies to overcome these time constraints.

Teacher has no good knowledge management. So far, very rarely given their laboratory management training. As long as there is no special training for laboratory managers. Such situation will greatly affect laboratory management handled.

\section{E. Discussion}

The survey results show there is a chemistry laboratory at the school, but it is rarely used for the laboratory doing practical work. The main obstacle is the cause is rarely implemented practical tools and materials that are not always available for all materials lab. Another obstacle is not all the tools in the laboratory can function properly. Perspective students on how and practical methods in line with the results of the observation of the subject teachers who said that the school has a chemical laboratory facilities but the number of
Table 2. Practical Implementation Observations

\begin{tabular}{lcc}
\hline \multicolumn{1}{c}{ Aspect } & $(\%)$ & Criteria \\
\hline Laboratory conditions & 50 & Less \\
Motivation of learners & 78 & Good \\
Implementation time & 60 & Enough \\
practicum & & \\
$\begin{array}{l}\text { Preparation and practical } \\
\text { Implementation }\end{array}$ & 70 & Enough \\
\hline
\end{tabular}

incomplete equipment and some tools that do not serve properly functioning.

Learners as a research subject has been assumed that the preparation and practical implementation has been operating at less good start because there are still some obstacles that complicate the practical implementation itself, but they can be overcome by other means. Results of preparation and implementation of practical observation in senior high school Tanjung pura showed good results it can be seen from the grouping lab set up well by the teacher to the students to work together when practical activities carried out. Guidance lab also remains an area that has received less attention. Due to practical guides that I have seen during my studies at school is still using makeshift lab guides. Which means that the practical guide packed with interesting yet.

Guidance lab still uses practical guidance in textbooks. So there is no practical handbook itself as a guide to learners in procedures practicum. This makes the learners are still many questions, especially in understanding the procedures or work steps in practical activities.

Practicum in teaching chemistry as the implementation of curriculum implemented in 2013 with many being developed. Implementation of practical activities at school can not be implemented for each study. Based on the results of the questionnaire, teacher practicum programmed only a maximum of 3 times in one semester. Consideration of practical implementation is minimal is because, according to the lab teacher takes a long time. However, in the implementation of learning in chemistry is not in line with expectations. This causes difficult students to practice the process,

Problems learners also become an obstacle in practical activities. Because students who were leading role in practical activities at school. Those who become a benchmark that can be said practicum running well or not. Usually the problem there are some students who do not want to obey even less practical to implement. Because there is no consciousness in the students the importance of following the lab but to add value to the academic as well as a container to hone psychomotor abilities of learners themselves.

Practical remain to be implemented as an objective in the curriculum in 2013 and as part of an integral chemistry learning with a variety of existing, but teachers as educators like to do some alternative solutions to overcome some of the obstacles that exist. Various solutions that teachers do not exist problem. Practical implementation are flocking adjusted number of existing tools cause only students who are active in the group are able to thrive. 
The use of virtual simulation as a substitute for the lab has also had the advantage. Practical does not require a lot of equipment, can be done at all places and can provide the opportunity to work over and over again when it finds difficult or interesting concept [14]. The survey shows many things that became an important part in a practicum and this is the sympathy for the principal, teachers, students and laboran. Practicum activities is needed and cannot be ignored because there is inquiry learning activities that in practical activities [15]. Students also need the guidance of a teacher for carrying out practical work.

Attention to the laboratory is expected to assist schools in the implementation and optimal chemical learning through practical activities. Competence and professionalism of teachers in a chemistry lab and learning should be given due attention and teachers role. Increased competence can be done by optimizing the subject teacher forums and training on labbased learning. Another effort that might be implemented to map the department of education is teacher competence in practical terms to keep existing policies in order to improve or increase the competence of teachers is not misplaced

\section{CONCLUSIONS}

Based on the results of data analysis and discussion, it can be concluded that the implementation of the chemistry lab at the senior high school in Tanjung Pura are as follows:

1. The results obtained show that the practical implementation at senior high school in Tanjungpura have less good criteria are reviewed based on the questionnaire responses of teachers and students. Some aspects that show fairly low percentage is the availability of time, equipment and materials as well as practical guidance, in addition to the motivational aspect of the environment is less supportive practicum.

2. The results also show that there are obstacles laboratory facilities are not utilized to the maximum; school support is limited, laboratory management is lacking, a factor less teacher teacher preparation; practical implementation is not helped by a laboratory or a laboratory technician; lack of supervision and guidance of teachers can lead students are less serious in carrying out practical work. As the material further research is necessary to guide the development and innovation of chemistry lab equipment that is simpler in order to facilitate teachers and students in learning

\section{REFERENCES}

[1] National Research Council, et al. "America's lab report: Investigations in high school science," National Academies Press, 2006, pp. 75-79.

[2] S, Karamustafaoğlu, "Improving the science process skills ability of prospective science teachers using the I diagrams," Eurasian Journal of Physics and Chemistry Education, vol 2, pp. 26-38, 2011.

[3] R.A. Rauf, et al, "Inculcation of science process skills in a science classroom," Asian Social Science, vol 8, pp. 47, 2013.

[4] S. Mutisya, M. Rotich, K. Paul, S. Rotich, "Conceptual understanding of science process skills and gender stereotyping: a critical component for inquiry teaching of science in Kenya's primary schools," vol 3, pp 361-369, 2013.

[5] F. Karsli and A. Ayas, "Developing a laboratory activity by using 5e learning on student learning models of factors affecting the reaction rate and improving scientific process skills," ProcediaSocial and Behavioral Sciences, vol 14, pp. 143-663, 2014.

[6] R. Trumper, "What Do We Expect from Students' Physics Laboratory Experiments ?," Journal of Science Education and Technology, vol 11, pp. 221-228, 2002.

[7] L. Marlina, "Manajemen Laboratorium Kimia. Manajer Pendidikan, vol 10, pp. 374-380. 2016.

[8] I. Wiratma \& G. Lanang, "Pengelolaan Laboratorium Kimia pada SMA Negeri di Kota Singaraja : (Acuan Pengembangan Model Panduan Pengelolaan Laboratorium Kimia Berbasis Kearifan Lokal Tri Sakti)," Jurnal Pendidikan Indonesia, vol 3, pp 2-5, 2015.

[9] A. Hofstein \& V.N Lunetta, "The laboratory in science education: Foundations for the twenty-first century," Science education, vol 88, pp. 28-54, 2004.

[10] N. Rustaman \& A. Riyanto, "Perencanaan dan Penilaian Praktikum di Perguruan Tinggi. Handout Program Applied Approach bagi Dosen baru Universitas Pendidikan Indonesia," pp. 13-25, 2003.

[11] S. Rahmiyati, "Keefektifan Pemanfaatan Laboratorium di Madrasah Aliyah Yogyakarta," Jurnal Penelitian dan Evaluasi Pendidikan, vol 11, pp. 88-100, 2008.

[12] F.J Purba, Z. Muchtar, R. Silaban, "Pengembangan Penuntun Praktikum Kimia Sesuai Model Pembelajaran Penemuan Dan Berbasis Proyek," Jurnal Penelitian Bidang Pendidikan, vol 21, pp. 21-28, 2015.

[13] G. Hollowell, J. Osler, Hester, L. April, "Computational and Genomic Analysis of Mycobacteriophage: A Longitudinal Study of Technology Engineered Biology Courses That Implemented an Inquiry Based Designed To Enhance Laboratory Practice, Encourage, and Empower Student Learning," I-Manager's Journal of Educational Technology, vol 11, pp. 39-45, 2015.

[14] B. Dalgarno, et al, "Effectiveness of a virtual laboratory as a preparatory chemistry resource for distance education students," Computers \& Education, vol 53, pp. 853-865, 2009.

[15] C. Tseng, H. Sir, \& C. Chin, "How to help teachers develop teaching inquiry: Perspectives from experienced science teachers," Research in Science Education, vol 43, pp. 809-825, 2013. 